\title{
Brief Introduction to the Book
}

The theory, methodology, technology, and achievements of research on botanical gardens worldwide are for the first time systematically reviewed and summarized, and form the foundation of Botanical Garden Science, PHYTOHORTOLOGY. Altogether there are 11 chapters.

Chapter 1 Botanical Garden and Botanical Garden Science, PHYTOHORTOLOGY

Chapter 2 The History of Botanical Gardens

Chapter 3 Ex-situ Conservation in Botanical Gardens

Chapter 4 Plant Introduction and Acclimatization in Botanical Gardens

Chapter 5 The Greenhouse System in Botanical Gardens

Chapter 6 Education in Botanical Gardens

Chapter 7 Landscape Planning, Design, and Architecture in Botanical Gardens

Chapter 8 The Operation and Administration of Botanical Gardens

Chapter 9 Major Botanical Gardens in China

Chapter 10 Characteristics and Review of World Famous Botanical Gardens

Chapter 11 Major Botanical Gardens All Over the World

Chapters 1 8, as Part One, are the "General Introduction and Fundamental Theories and Principles of Botanical Garden Science, PHYTOHORTOLOGY," and Chapters 9 11, as Part Two, are the text for "Individual Botanical Gardens."

Major achievements in botanical gardens, including research on plant introduction and acclimatization, economic plants, and environmental plants, were presented in this book, and the authors have pointed out the direction and the way for botanical gardens to serve the national economy. Principles and methods for plant conservation in botanical gardens were suggested. Based upon historical facts, the authors interpreted the dialectical relationship between "conservation" and "utilization". In accordance with the true situation in China the "Developmental Strategy for the Chinese Botanical Garden System" was proposed. The use of modern information techniques for living collection records in botanical gardens was particularly discussed. The features and historical uniqueness of the development of greenhouses in botanical gardens both domestic and foreign were analyzed, and the role and the effectiveness of the demonstration of plant diversity in greenhouses were emphatically summarized. The particularity and foresight of scientific popularization (education programs) and tourism, as well as the complexity of operation and management in botanical garden, were discussed and concluded. The features of various art schools and styles in landscaping design, including ancient, modern, eastern and western were introduced and reviewed. The design and extent of landscape construction needed in Chinese botanical gardens were discussed.

Based on the achievements of the authors' studies of innovations in concepts, theories and practice on plant introduction and acclimatization, ex-situ conservation and stress cultivation of medicinal plants, and plant diversity conservation and utilization in cities were presented.

Owing to the importance of visualization, more than 2,000 pictures were selected for this book to show and transfer the information, thought, feelings, and inspiration that could not be expressed by words and text alone. In addition, there are introductions to more than 200 
individual botanical gardens all over the world in order to allow readers to easily recognize those botanical gardens, and to deepen their feelings and understanding as well as to create the thought leap in their minds. Many of those pictures were especially provided by botanical gardens both domestic and abroad.

This book is appropriate for readers including those who work in botanical gardens, on plant conservation, for landscape and scenery areas and natural protected land, on city construction, on landscape art and architecture, in gardening and landscaping, on education, and policy makers and administration leaders.

This English version is translated from the Chinese version published in 2005. But, some new data and pictures are included to replace the original ones in order to present a little more updated information. 